\title{
SEGMENTASI LAYANAN INTERNET BANKING
}

\author{
Ellen Theresia Sihotang ${ }^{{ }^{*}}$ \\ ${ }^{1}$ Sekolah Tinggi Ilmu Ekonomi Perbanas Surabaya \\ *Ellen@perbanas.ac.id
}

\begin{abstract}
The purpose of this study is to analyze internet banking's users based on their experiences. It can be used to set marketing program of internet banking that appropriate with customers needs, in order to anticipate tight competition. This research methods starts with focus group discussion and clustering analysis to classify 312 respondents of internet banking users based on demographic, benefit and behavioral segmentation. The sampling method uses purposive sampling and snowball sampling. K-Means Clustering method's produces four optimal clusters. The benefit orientation of the first cluster in on time saving. Second cluster, concern on the ease of getting and operating internet banking so this cluster does not need auxiliary features such as video guide to use internet banking. The third cluster's orientation is on the modern lifestyle and the ease of getting and operating internet banking service with detailed daily mutation transaction The fourth cluster, concerns on the detailed daily mutation transaction but they are not sure with the security of personal data via internet banking.
\end{abstract}

Keywords: Segmentation, Clustering, Internet Banking, Consumer Behaviour

\section{PENDAHULUAN}

Kehadiran teknologi internet membuat dunia menjadi tanpa batas. Memberikan kemudahan di berbagai sektor, terutama pada kegiatan pemasaran. Bukan hanya pelanggan yang dipermudah tetapi juga mempermudah kegiatan pemasaran itu sendiri. Sejumlah informasi yang diperlukan oleh calon pelanggan maupun pelanggan dapat dengan segera diperoleh. Berdasarkan survei yang dilakukan oleh We Are Social.com, jumlah pengguna internet di dunia yang aktif menggunakannya, sampai dengan Januari 2016 adalah 3,42 milyar dengan tingkat penetrasi $46 \%$. Angka tersebut memberikan peluang bagi sektor perbankan untuk meningkatkan layanan berbasis elektronik, yang lebih cepat dan fleksibel. Layanan tersebut adalah perbankan elektronik (electronic banking) sebagai pengembangan dari jalur layanan konvensional yang masih tetap ada sampai saat ini.
Sektor perbankan menyadari bahwa layanan konvensional saja tidak cukup untuk meraih target keuntungan, tetapi juga perlu menyediakan layanan mobile, terutama bagi para pelanggan yang memiliki pergerakan atau aktivitas cukup tinggi (Chin et al., 2012). Layanan perbankan elektronik (electronic banking) meliputi, mesin teller otomatis (Automatic Teller Machine/ATM), internet banking, phone banking, dan short messages service banking (sms banking). Internet banking merupakan pengembangan dari ATM karena memiliki tampilan fitur yang sama. Bank Indonesia menjelaskan internet banking adalah layanan untuk melakukan transaksi perbankan (transaksi keuangan maupun bukan keuangan), menggunakan komputer yang terhubung dengan jaringan internet bank. Namun, seiring dengan makin berkembangnya teknologi alat komunikasi, akses internet banking tidak hanya sebatas menggunakan komputer tetapi dapat juga diakses 
menggunakan alat komunikasi seperti telepon pintar (smartphone) atau gadget, sehingga salah satu infrastuktur terpenting beroperasinya layanan internet banking adalah tersedianya jaringan internet.

Secara umum Asosiasi Penyelenggara Jasa Internet Indonesia juga memberikan gambaran perihal penggunaan layanan internet banking di Indonesia. Berdasarkan survey 2015, sebagian besar internet banking digunakan untuk cek saldo senilai $80 \%$ dan transfer dana, sebesar 63\%. Akses untuk transaksi melalui internet banking mayoritas dilakukan menggunakan akses mobile, sebesar 56,5\%.

Berdasarkan data pengguna layanan internet banking dari 6 bank besar di Indonesia. Tahun 2014 total pengguna internet banking mencapai 10 juta orang, dengan nilai transaksi melalui layanan internet banking sebesar Rp 5.617 triliun. Bank Central Asia (BCA) memiliki total nilai transaksi Rp 5.349 triliun, hampir menguasai keseluruhan nilai transaksi internet banking di Indonesia. Peringkat kedua berdasarkan nilai transaksinya adalah Bank Mandiri sebesar Rp 144 triliun, kemudian Bank Rakyat Indonesia (BRI) diperingkat ketiga dengan total transaksi sebesar Rp 86 triliun dan diperingkat ke-empat adalah Bank Negara Indonesia (BNI) senilai Rp 38 triliun (Sharing Vision.com 2015). Mengacu pada data tersebut diperoleh gambaran layanan internet banking yang cukup dikenal dipasaran dan menguasai pangsa pasar adalah KlikBCA kemudian disusul dengan layanan internet banking Mandiri. Urutan ketiga dan ke-empat masih terjadi pergantian antara internet BRI dengan BNI, artinya ke-empat bank tersebut berada dalam arena persaingan yang cukup ketat dalam memasarkan layanan tersebut.

Survey yang dilakukan oleh Price waterhouse Coopers (PwC) Indonesia perihal Survei Perbankan Indonesia 2015, menyatakan bahwa sebagian besar nasabah bank mengharapkan transaksi secara konvesional bisa diselesaikan melalui jaringan digital. Keinginan dan kebutuhan tersebut didukung juga dengan adanya penetrasi alat komunikasi berupa telepon pintar (smartphone), sehingga untuk memenuhi keinginan tersebut, pada tahun 2015, para bankir Indonesia memutuskan prioritas utama investasi layanan perbankan pada layanan internet banking (Pwc.com 2015).

Kehadiran layanan internet banking tidak terlepas dari kegiatan pemasarannya. Bukan hanya sekedar menyediakan layanan tersebut kepada pelanggan, namun perlu juga mempelajari dan beradaptasi terhadap kebutuhan pelanggan yang dinamis (Maenpaa, 2006). Pemahaman terhadap kebutuhan dan keinginan pelanggan yang bersifat dinamis dapat dilakukan dengan mengenali karakteristik pasar. Konsep yang digunakan adalah segmentasi pasar untuk menetapkan strategi pemasaran yang tepat pada pasar sasaran, sehingga mampu bersaing di pasaran dan peringkat layanan terhadap pelanggan dapat semakin meningkat.

Berdasarkan pada uraian tersebut maka yang menjadi perhatian utama dari penelitian ini adalah menganalisis para pengguna layanan internet banking berdasarkan pengalamannya, dalam rangka mengaplikasikan program pemasaran internet banking yang berorientasi pada kebutuhan dan keinginan pelanggan sebagai antisipasi menghadapi persaingan yang semakin ketat. Adapun rumusan masalah dari penelitian ini meliputi 3 hal, yaitu: 1) seperti apakah profil dan karakter pelanggan pengguna layanan internet banking; 2) seperti apakah segmen pasar layanan internet banking; dan 3) jenis transaksi yang paling sering digunakan oleh pengguna layanan internet banking.

\section{Segmentasi Pasar}

Proses membagi pelanggan atau pelanggan potensial ke dalam kelompokkelompok atau segmen-segmen yang berbeda, dengan tingkat kebutuhan yang sama atau sebanding dalam rangka memenuhi kebutuhan dan keinginan pelanggan secara tepat merupakan pengertian dari segmentasi pasar (McDonald dan Dunbar, 2004:37). Artinya, segmentasi 
merupakan serangkaian proses yang mengidentifikasi pelanggan ke dalam kelompok yang cenderung homogen dan mempertemukan pemasar pada kebutuhan serta keinginan pelanggan secara efektif. Menurut Kotler dan Amstrong (2016:232), segmentasi yang efektif memiliki lima kriteria utama, yaitu terukur, dapat diakses, substansial, dapat dibedakan dan merespon secara berbeda elemen maupun program bauran pemasaran yang berbeda, serta dapat ditindak lanjuti. Mullins et al (2008:174) menjelaskan segmentasi pasar memiliki beberapa tujuan. Tujuan terpenting adalah untuk mengidentifikasi segmen homogen yang berbeda dari segmen lainnya dalam elemen-elemen bauran pemasaran-4P (product, price, place, promotion). Berkaitan dengan identifikasi tersebut, tujuan berikutnya adalah untuk menentukan kriteria setiap segmen serta menetapkan ukuran dan potensi dari setiap segmen. Selanjutnya, artikel New Criteria for Market Segmentation (Yankelovich, 1963), menyebutkan ada tujuh manfaat segmentasi pasar, salah satu yang terpenting adalah menangkap sinyal dari kecenderungan utama di pasar yang berubah dengan cepat. Berkaitan dengan pandangan terhadap manfaat segmentasi pasar, artikel berjudul Rediscovering Market Segmentation (Yankelovich,2006), mengungkapkan manfaat segmentasi pasar, meliputi cerminan strategi perusahaan; menunjukkan sumbersumber pendapatan atau keuntungan yang dapat diperoleh; mengidentifikasi nilai, sikap dan keyakinan pelanggan terhadap barang atau jasa yang ditawarkan, fokus terhadap perilaku pelanggan yang sesungguhnya; memberikan masukan yang masuk akal terhadap manajemen perusahaan serta mengakomodasi atau mengantisipasi perubahan pasar maupun perilaku pelanggan.

Proses segmentasi terdiri dari dua fase utama yaitu pengembangan segmen dan memilih segmen serta memprioritaskan segmen yang telah dipilih tersebut. Kedua fase tersebut secara terperinci dijelaskan oleh McDonald dan Dunbar (2004:56-58) kedalam empat tahapan melalui tujuh langkah, sebagai berikut:
Tahap 1: pasar dan cara kerjanya, terdiri dari dua langkah, yaitu mendefinisikan dan pemetaan pasar. Mendefinisikan pasar yaitu penetapan ruang lingkup segmentasi secara spesifik dan memahami apa yang mendasari pelanggan memasuki pasar.

Pemetaan pasar artinya menampilkan pasar yang telah ditetapkan kedalam suatu bagan arus yang saling berkaitan ketika ada proses pembelian sampai kepada pengguna akhir berlanjut ke pesaing, dilanjutkan ke sejumlah pemasok dan kembali lagi ke pengguna akhir;

Tahap 2: pengambilan keputusan dan sejumlah transaksi sebagai langkah ketiga dan lanjutan dari pemetaan. Siapa yang membeli dan apa yang dibeli dapat diidentifikasi sebagai profil standar dari sekelompok pembeli;

Tahap 3: segmentasi pasar, mencakup langkah ke-empat yang memahami alasan mengapa produk dicari oleh pihak pembeli, termasuk juga ketika menetapkan beberapa alternatif penting ditawarkan serta harga dari sejumlah transaksi pembelian. Langkah kelima menetapkan segmen dengan menjelaskan teknik yang digunakan untuk mengelompokan pasar;

Tahap 4: merupakan bagian dari fase kedua (memilih segmen), sebagai langkah ke-enam yang berkaitan dengan daya tarik segmen. Mengukur apa yang menjadi daya tarik segmen, dengan menetapkan beberapa kriteria tertentu. Langkah ke-tujuh merupakan daya saing atau kompetitif perusahaan berdasarkan pada kekuatan dari segmen perusahaan yang telah ditetapkan. Kombinasi daya tarik segmen dengan daya saing perusahaan akan membangun gambaran strategis pasar yang dapat digunakan untuk memilih segmen yang sesuai dengan pencapaian tujuan perusahaan.

\section{Teknik Segmentasi}

Secara umum teknik segmentasi terdiri dari apriori dan post-hoc. Machauer dan Morgner (2001) menjelaskan segmentasi apriori beranggapan pada adanya hubungan yang signifikan antara karakteristik eksternal pelanggan dengan kebutuhannya, sehingga 
kriteria ekonomi dan demografi merupakan indikator penentu untuk mengetahui struktur dan pola kebutuhan serta keinginan pelanggan. Pendekatan post-hoc dikenal juga sebagai pendekatan segmentasi secara modern. Teknik ini berdasarkan pada penelitian dengan serangkaian teknik statistik yang canggih. Pengumpulan data dilakukan setelah produk tersebut digunakan oleh pelanggan kemudian menanyakannya untuk diolah dan dianalisis. Faktor demografi ataupun geografi masih bisa digunakan dalam pengukurannya. Namun, umumnya lebih sering menggunakan pendekatan keperilakuan (behavior), sikap (attitude) atau manfaat yang dicari (benefit sought).

\section{Dasar Segmentasi}

Dasar segmentasi dapat menjadi bagian dari variabel yang akan diteliti. Secara deskriptif dapat dilakukan melalui analisis geografis, demografis, dan psikografis. Tetapi, pertimbangan lainnya yang dapat digunakan adalah melalui perilaku pelanggan.

\section{Segmentasi Geografis}

Segmentasi geografis, membagi pasar kedalam berbagai unit geografis yang berbeda, seperti negara, wilayah, kabupaten, kota atau lingkungan sekitar perusahaan (Kotler dan Armstrong, 2016:223).

\section{Segmentasi Demografi}

Pendekatan yang digunakan adalah variabel kependudukan. Kotler dan Keller (2016:249) menjelaskan variabel-variabel demografi seperti usia, ukuran keluarga, siklus hidup keluarga, jenis kelamin, penghasilan, pekerjaan, pendidikan, agama, ras, generasi, kebangsaan, dan kelas sosial. Variabel tersebut paling sering digunakan pada kegiatan pemasaran karena berkaitan erat dengan kebutuhan dan keinginan pelanggan. Pengukurannya pun tidak rumit.

\section{Segmentasi Psikografi}

Segmentasi psikografi berakar dari konsep yang disebut dengan riset motivasi (Snellman, 2000:10). Penelitian tersebut mengacu pada pemahaman akan jiwa pelanggan dengan menggunakan metode dari klinik psikologi. Tujuannya untuk memberikan gambaran manusia sebagai pelanggan, dengan berfokus kepada aktivitas, minat, dan opini (Wells dan Tigert, 1971). Dasar mengelompokan pelanggan secara terperinci tidak hanya berdasarkan pada variabel-variabel demografi saja. Plummer (1974) menjelaskan segmentasi gaya hidup atau psikografi mengukur serangkaian aktivitas manusia yang terkait dengan bagaimana menghabiskan waktu dan uang. Minat pada apa yang dianggap paling penting dengan lingkungan sekitarnya. Pandangan terhadap diri sendiri maupun terhadap orangorang disekeliling serta beberapa karakteristik dasar seperti tahapan siklus hidup, penghasilan, pendidikan serta tempat tinggal. Pengelompokan berdasarkan pada sistem nilai dan gaya hidup (Value and Lifestyle System/VALS dapat juga digunakan pada segmentasi psikografi.

Prinsip dasarnya adalah sumber daya dan motivasi pelanggan.

\section{Segmentasi Keperilakuan}

Kotler dan Keller (2016:259)

menjelaskan beberapa variabel yang digunakan untuk mengukur keperilakuan pelanggan, adalah sebagai berikut:

a. kejadian tertentu (occasions), yang bersifat sementara dan bisa dijelaskan dengan baik;

b. status pengguna manfaat (user status), yang meliputi pengguna potensial, pengguna produk pertama kali, pengguna rutin, mantan pengguna dan non pengguna;

c. tingkat penggunaan (usage rate), meliputi pengguna ringan, sedang dan berat;

d. tahap kesiapan pembeli (buyer-readiness stage), didasarkan pada keberadaan produk yang tidak disadari, disadari, diketahui, menarik, diinginkan dan dibeli oleh kelompok tertentu;

e. status loyalitas (loyalty status), biasanya oleh pemasar dibagi dalam empat kelompok yaitu pelanggan yang hanya membeli satu merek sepanjang waktu 
(hard-core loyals), pelanggan yang loyal kepada dua atautiga merek (split loyals), pelanggan yang beralih loyalitas dari satu merek ke merek yang lain (shifting loyals), serta pelanggan yang tidak menunjukkan loyalitas pada merek apapun (switchers),

f. sikap (attitude), terbagi dalam lima sikap terhadap produk yaitu antusias, positif, apatis, negatif dan agresif,

g. berbagai dasar kombinasi (multiple bases), merupakan segmentasi dengan menggabungkan perilaku pelanggan yang berbeda. Mampu memberikan pandangan secara menyeluruh dan terpadu terhadap segmen pasar.

\section{Segmentasi Manfaat}

Haley (1968), mengungkapkan manfaat yang dicari oleh pelanggan dengan menetapkan perilakunya merupakan pendekatan yang lebih akurat, daripada hanya menggunakan karakteristik demografi maupun volume yang dikonsumsi. Manfaat yang diinginkan dari suatu produk oleh pelanggan memiliki hubungan sebab akibat dengan perilaku pembelian pelanggan dimasa yang akan datang. Segmentasi manfaat memiliki kekuatan sebagai prediktor perilaku pelanggan dalam kegiatan pemasaran yang berkelanjutan, dengan demikian segmentasi manfaat tidak hanya digunakan untuk mengembangkan produk baru dan memperbaiki posisi produk dipasaran atau menghentikan produk yang lama tetapi dapat memfasilitasi proses komunikasi dua arah antara pelanggan dengan pihak perusahaan (Minhas dan Jacobs, 1996).

Segmentasi berdasarkan persepsi manfaat pada pengguna layanan internet banking menghasilkan 4 klaster. Klaster 1 (suspicious), ragu dengan sistem keamanan layanan internet banking. Lebih memilih melakukan transaksi dengan datang ke bank. Klaster 2 (eager), memiliki pandangan positif terhadap layanan internet banking dan dapat menaikkan status sosialnya. Klaster 3 (reluctant), menggunakan layanan internet banking hanya bergantung pada dimensi keamanan, namun tidak memiliki pengalaman terhadap apresiasi sosial dari penggunaan layanan tersebut. Klaster 4 (practice), menggunakan layanan internet banking lebih memudahkan untuk mendapatkan informasi, kualitas layanannya lebih bagus dan konsekuensinya lebih menghemat waktu (Maenpaa:2006).

Segmentasi nasabah bank berdasarkan pada manfaat yang diinginkan dari keberadaan bank, menghasilkan empat klaster juga. Klaster 1 (service oriented), beroritentasi pada kualitas layanan yang baik ketika berinteraksi dengan karyawan bank maupun dengan sejumlah fitur perbankan. Klaster 2 (rate sensitive) merupakan klaster yang utamanya mempertimbangkan harga ketika memilih menggunakan jasa layanan suatu bank. Klaster 3 (promotional incentive), adalah klaster yang menginginkan adanya tambahan promosi dari setiap produk perbankan yang ditawarkan dan ada

\section{METODE}

Populasi dari penelitian ini adalah pengguna layanan internet banking. Metode penyampelan yang digunakan adalah kombinasi purposive sampling dengan snowball sampling. Teknik pengumpulan data penelitian ini diawali dengan kelompok diskusi fokus (focus group discussion) dan kuisioner Penyebaran kuisioner dilakukan secara langsung kepada responden (manual) dan melalui surat elektronik (e-mail). Jumlah responden yang layak sebagai sampel pada penelitian ini berjumlah 312 orang sebagai pengguna layanan internet banking yang masih aktif. Variabel yang digunakan pada penelitian ini adalah variabel demografi keperilakuan dan manfaat. Skala nominal digunakan untuk mengukur variabel demografi dan keperilakuan. Variabel manfaat menggunakan skala likert.

Metode analisis data yang digunakan adalah teknik interdependensi dengan beberapa tahapan sebagai berikut;

a. Tahap pertama adalah analisis faktor konfirmatori. Analisis ini digunakan untuk mengetahui hubungan antar variabel yang sudah tersedia berdasarkan pada 
penelitian-penelitian sebelumnya dan hubungan matriks korelasi.

b. Tahap kedua adalah klastering, merupakan proses mengelompokkan sejumlah responden yang memiliki kesamaan karakteristik berdasarkan variabel demografi, manfaat dan keperilakuan.

c. Tahap ketiga adalah analisis klaster. Metode yang digunakan adalah $K$-means clustering.

d. Tahap ke-empat, melakukan uji $\mathrm{F}$ atau ANOVA satu arah terhadap klaster-klaster yang terbentuk. Uji ANOVA satu arah merupakan tahapan pengujian untuk mengetahui apakah jumlah klaster yang dipilih memiliki perbedaan antara satu dengan lainnya berdasarkan jarak dari masing-masing klaster, dengan nilai signifikan kurang dari 0,05.

\section{Uji Validitas}

Penelitian ini diawali dengan face validity kuisioner dari seorang ahli pemasaran. Selanjutnya adalah uji validitas dan reabilitas dengan sampel kecil (pretest) 30 responden, sebelum melakukan penggujian terhadap sampel besar. Hasil uji validitas terhadap konstruk manfaat yang terdiri dari empat dimensi diperoleh nilai Uji Kaiser-Meyer-Olkin Measure of Sampling Adequacy (KMO MSA) sebesar 0,833. Nilai tersebut lebih tinggi dari nilai minimum 0,5 (Hair et al., 2010:92), sehingga analisis faktor dapat diterima untuk menganalisis 22 pertanyaan kuisioner dengan 4 dimensi variabel manfaat. Ke-empat dimensi tersebut meliputi kenyamanan, keamanan, status sosial dan fitur-fitur bantuan.

Tabel 1. Nilai KMO dan Barlett's Test Analisis Faktor Variabel Manfaat

\begin{tabular}{|c|c|c|c|c|}
\hline \multicolumn{5}{|c|}{ Nilai KMO \& Barlett's Test } \\
\hline Variabe & $\begin{array}{l}\text { Keiser- } \\
\text { Meyer- } \\
\text { Olkin } \\
\text { Measure } \\
\text { of } \\
\text { Sampling } \\
\text { Adeguacy }\end{array}$ & $\begin{array}{l}\text { Bartlett's } \\
\text { Test of } \\
\text { Sphericity } \\
\text { Approx } \\
\text { Chi- } \\
\text { Square }\end{array}$ & Df & Sig \\
\hline Manfaat & 0,833 & 2700,417 & 231 & 0,000 \\
\hline
\end{tabular}

Komponen yang tidak berkelompok pada satu faktor dan bernilai kurang dari 0,35 merupakan komponen dimensi variabel yang tidak valid. Sesuai dengan ketentuan dari SOLO Power Statitical Software, Inc., 1993 (Hair et al., 2010:116). Faktor 1 ditempati oleh dimensi kenyamanan sejumlah 5 dimensi yang valid. Dimensi fitur-fitur bantuan menempati faktor 2 dengan jumlah dimensi yang valid adalah 4. Faktor 3 ditempati oleh dimensi status sosial berjumlah 2, sedangkan dimensi keamanan menempati faktor 4 dengan jumlah dimensi yang valid adalah 3 . Total dimensi variabel manfaat yang valid untuk analisis klaster berjumlah 14 .

\section{Tabel 2. Factor Loading Komponen Matriks}

\begin{tabular}{lcccc}
\hline \multirow{2}{*}{ Variabel } & \multicolumn{4}{c}{ Komponen } \\
& 1 & 2 & 3 & 4 \\
\hline K1 & 0,698 & & & \\
K2 & 0,839 & & & \\
K3 & 0,864 & & & \\
K4 & 0,841 & & & \\
K5 & & & & \\
K6 & & & & \\
K7 & & & & \\
K8 & & & & \\
K9 & 0,692 & & & \\
K10 & & & & \\
\hline KA11 & & & & 0,901 \\
KA12 & & & & 0,878 \\
KA13 & & & & \\
KA14 & & & & \\
\hline SS15 & & & 0,544 & \\
SS16 & & & 0,741 & \\
\hline F17 & & & \\
F18 & & & & \\
F19 & & 0,714 & & \\
F20 & & 0,877 & & \\
F21 & & 0,873 & & \\
F22 & & 0,675 & \\
Sumber: data diolah & &
\end{tabular}

Sumber: data diolah

Uji keandalan menggunakan uji statistik Cronbach Alpha. Batas terendah dari nilai Cronbach Alpha adalah 0,60 untuk penelitian eksploratory, namun secara umum senilai 0,70 (Hair et al., 2010:124). Berdasarkan pada Tabel 3, perihal Hasil Uji Keandalan, 4 dimensi variabel manfaat dapat dikatakan telah memenuhi syarat keandalan. 
Tabel 3. Hasil Uji Keandalan

\begin{tabular}{lcc}
\hline \multicolumn{1}{c}{$\begin{array}{c}\text { Dimensi } \\
\text { Variabel }\end{array}$} & $\begin{array}{c}\text { Cronbach' } \\
\text { s Alpha }\end{array}$ & Ket \\
\hline Kenyamanan (K) & 0,770 & Andal \\
Keamanan (KA) & 0,859 & Andal \\
Status Sosial (SS) & 0,718 & Andal \\
Fitur-fitur Bantuan (F) & 0,785 & Andal \\
\hline Sumber: data diolah. & &
\end{tabular}

\section{HASIL DAN PEMBAHASAN}

\section{Analisis Klaster 312 Responden}

Metode klastering yang digunakan adalah $k$-means clustering, mengingat jumlah responden termasuk berukuran besar. Pemilihan jumlah klaster yang optimal berdasarkan pada dua hal utama. Jumlah dimensi variabel pembentuk klaster berbeda secara signifikan dengan standar penilaian signifikan kurang dari 0,05 dan tingkat penyebaran anggota masing-masing klaster tidak jauh berbeda. Tahapan untuk menemukan klaster yang optimal

dimulai dari jumlah klaster yang terkecil terlebih dahulu, yaitu 2 klaster, 3 klaster, 4 klaster dan 5 klaster. Pembagian 312 responden menghasilkan klaster yang optimal pada 4 klaster. Berdasarkan jumlah anggotanya, seperti yang tercantum pada Tabel 4, menggambarkan sebaran anggota yang tidak menumpuk, dengan demikian dapat dilakukan uji Anova satu arah terhadap 4 klaster tersebut.

Tabel 4. Jumlah Anggota 4 Klaster

\begin{tabular}{lrr}
\hline Klaster & 1 & 105.000 \\
& 2 & 63.000 \\
& 3 & 78.000 \\
& 4 & 66.000 \\
\hline Valid & 312.000 \\
\hline Missing & .000 \\
\hline \multicolumn{2}{l}{ Sumber: data diolah }
\end{tabular}

Hasil uji Anova terhadap dimensi variabel pembentuk 4 klaster, secara keseluruhan bernilai signifikan 0,000 kurang dari 0,05. Artinya, dapat dilanjutkan analisis terhadap pusat akhir klaster. Nilai pusat klaster menggambarkan karakteristik 4 klaster yang telah ditetapkan, berdasarkan manfaat yang telah dirasakan oleh pengguna internet banking. Analisis terhadap masing-masing klaster adalah sebagai berikut:

\section{Klaster 1}

Klaster ini memiliki berjumlah 105 orang $(33,65 \%)$. Nilai pusat tertinggi dimiliki oleh klaster ini dibandingkan dengan 3 klaster lainnya. Manfaat yang dirasakan oleh klaster ini adalah penggunaan layanan internet banking menghemat waktu tanpa harus datang ke bank untuk melakukan transaksi perbankan.

\section{Klaster 2}

Jumlah responden pada klaster ini adalah 63 orang $(20,19 \%)$. Klaster ini memiliki nilai pusat klaster terendah dibandingkan dengan ketiga klaster lainnya. Fitur bantuan berupa video panduan pada website layanan internet banking bukan sebagai manfaat yang diharapkan karena memiliki nilai pusat klaster terendah pada klaster 2. Namun demikian, klaster ini menggunakan layanan internet banking karena proses mendapatkan melalui petugas bank mudah sehingga melalui layanan tersebut pelanggan merasakan penghematan waktu sebagai bagian dari dimensi kenyamanan yang dirasakan.

\section{Klaster 3}

Anggota klaster ini 78 orang (25\%). Nilai pusat terendah pada klaster ini adalah pada dimensi status sosial yang berkaitan dengan mengikuti tren. Klaster ini menggunakan internet banking bukan untuk mengikuti tren tetapi lebih kepada status sosial yang terkesan gaya hidupnya modern. Kemudahan pengoperasian dan proses mendapatkan internet banking, dilengkapi dengan fitur bantuan mutasi harian transaksi secara terperinci merupakan manfaat yang dirasakan oleh sejumlah responden pada klaster ini.

\section{Klaster 4}

Jumlah anggota klaster ini adalah 66 orang $(21,15 \%)$. Klaster ini tidak yakin bahwa data pribadi akan aman dengan menggunakan internet banking. Fokus dari klaster ini lebih kepada manfaat tersedianya fitur-fitur bantuan, terutama yang berkaitan dengan mutasi harian transaksi secara rinci. 
Uji Beda Klaster (Analisis Anova Satu Arah)

Penggujian perbedaan dari klaster yang dipilih berdasarkan jarak antar pusat klaster dengan menggunakan Anova Satu Arah (Uji F). Tujuannya untuk memastikan masingmasing klaster yang telah dipilih memiliki tingkat perbedaan. Hasil uji Anova satu arah terhadap jarak antar pusat klaster memberikan gambaran bahwa masingmasing klaster memiliki perbedaan dengan tingkat signifikansi 0,000 lebih kecil dari nilai 0,05 dengan nilai $F$ sebesar 14,817.

Tabel 5. Anova Jarak Antar Pusat Klaster

\begin{tabular}{lrrrrr}
\hline & $\begin{array}{l}\text { Sum of } \\
\text { Squares }\end{array}$ & df & $\begin{array}{l}\text { Mean } \\
\text { Squar } \\
\text { e }\end{array}$ & $F$ & Sig \\
$\begin{array}{l}\text { Between } \\
\text { Groups }\end{array}$ & 26.302 & 3 & 8,767 & 14,817 & 0,000 \\
\hline $\begin{array}{l}\text { Within } \\
\text { Groups }\end{array}$ & 182.248 & 308 &, 592 & & \\
Total & 208.549 & 311 & & & \\
\hline
\end{tabular}

Sumber data : data diolah

\section{Karakteristik Demografi Keperilakuan 4 Klaster}

Variabel demografi dan keperilakuan di ukur dengan tabulasi silang (crosstab) terhadap 4 klaster dengan uji Chi squares untuk mengetahui hubungan yang signifikan antara variabel demografi dan keperilakuan terhadap 4 klaster yang telah dipilih. Jenis kelamin, usia dan jenis pekerjaan tidak berpengaruh signifikan terhadap 4 klaster yang telah dipilih, karena nilainya lebih dari 0,05 . Empat klaster yang dipilih semua berusia pada rentang 25-34 tahun dan mayoritas berjenis kelamin perempuan. Tingkat pendidikan dan penghasilan memiliki pengaruh signifikan terhadap 4 klaster dengan nilai signifikan kurang dari 0,05 . Semakin tinggi tingkat pendidikan dipandang mampu mengoperasikan komputer dan telah terbiasa dengan internet (Arkinci et $a l$, 2004). Tingkat pendidikan yang tinggi juga selaras dengan tingkat penghasilan yang diperoleh (Maenpaa, 2006). Berkaitan dengan hasil dari penelitian ini, rentang penghasilan dari pengguna layanan internet banking berkisar pada nominal lebih dari Rp 2 juta sampai dengan lebih dari Rp 8 juta.
Artinya pengguna internet banking pada penelitian ini memiliki tingkat pendidikan yang tinggi selaras dengan tingkat penghasilannya. Karakteristik pendidikan dari 4 klaster yang dipilih adalah sarjana. Klaster 1 dan 4 , tingkat penghasilan pada rentang nominal $\mathrm{Rp}$ 2.000.001-Rp 4.000.000,-Klaster 2 memiliki rentang nominal Rp 4.000.001-Rp 6.000.000,-. Klaster 3, memiliki penghasilan senilai lebih dari Rp 8.000.000,-. Pengukuran terhadap variabel keperilakuan meliputi dimensi alasan utama menggunakan internet banking, periode waktu telah menggunakan internet banking, fitur yang paling sering diakses serta alat yang digunakan untuk akses internet banking. Periode waktu penggunaan dan fitur layanan internet banking memiliki hubungan yang signifikan terhadap 4 klaster. Masing-masing memiliki nilai 0,013 dan 0,037 lebih kecil dari 0,05. Klaster 1 telah menggunakan layanan internet banking pada rentang 3-4 tahun. Klaster 2 dan 4 selama lebih dari 5 tahun. Klaster 3 telah menggunakan internet banking pada rentang waktu 4-5 tahun. Fitur transaksi yang paling sering diakses oleh klaster 1, 2, dan 3 adalah pengiriman uang. Klaster 4 adalah cek tagihan dan pengiriman uang. Empat klaster tersebut memiliki kesamaan alasan terhadap penggunaan internet banking untuk memudahkan bertransaksi. Smartphone sebagai alat yang digunakan untuk akses internet banking.

Hasil dari penelitian ini menggambarkan bahwa segmentasi pengguna layanan internet banking tidak cukup hanya menggunakan variabel demografi saja, karena empat klaster tersebut hampir serupa. Tingkat pendidikan dan penghasilan rata-rata perbulan dapat dijadikan informasi utama untuk menentukan target pasar pengguna layanan internet banking karena memiliki hubungan yang signifikan dengan empat klaster tersebut. Periode waktu telah menggunakan layanan internet banking beserta fitur-fitur layanan dapat dijadikan dasar untuk merancang pengembangan layanan internet banking. 
Pengembangan fitur-fitur layanan internet banking di masa akan datang lebih berfokus kepada fungsi utama dari layanan tersebut. Berdasarkan pada hasil penelitian ini, tiga dari empat klaster lebih sering menggunakan fitur layanan pengiriman uang. Klaster 4, mayoritas menggunakan internet banking untuk cek tagihan dan pengiriman uang. Artinya pengembangan fitur-fitur lebih diarahkan untuk mendukung kelancaran dan kemudahan penggunaanya, dengan meningkatkan sistem keamanan bertransaksi. Fitur-fitur utama maupun bantuan, pengembangannya berdasarkan pada keinginan dan kebutuhan pengguna layanan internet banking yang nantinya akan memberikan kenyamanan berupa penghematan waktu, tanpa harus datang ke bank. Kenyamanan tersebut didukung juga dengan keamanan bertransaksi sehingga efisiensi pelayanan dan biaya dapat tercapai.

Pemasaran layanan internet banking pada kalangan usia muda dan tingkat pendidikan yang tinggi merupakan pasar sasaran yang potensial. Penjualan Layanan internet banking akan lebih baik dilakukan secara silang (cross selling). Terutama kepada para pelanggan (nasabah) yang telah memiliki rekening simpanan seperti tabungan, giro, deposito maupun rekening pinjaman. Pemasaran tidak hanya ditujukan kepada sejumlah pelanggan lama tetapi juga terhadap pelanggan baru sehingga secara tidak langsung pihak bank telah mengkomunikasikan beberapa produknya. Para pelanggan pengguna layanan internet banking dapat mengalami peubahan keperilakuan yang berpengaruh terhadap manfaat yang diinginkannya. Pihak bank, sebaiknya melakukan penelitian secara rutin, sehingga target dan posisi pasar akan semakin jelas melalui penerapan strategi pemasaran yang tepat.

Secara terinci, hasil dari penelitian ini diperoleh 4 klaster sebagai berikut:

\section{Klaster 1}

Karakteristik klaster ini memilih menggunakan layanan internet banking berkaitan dengan penghematan waktu bertransaksi tanpa harus datang dan antri di bank. Mayoritas berada pada rentang usia 2534 tahun. Pekerjaannya adalah sebagai karyawan dengan tingkat penghasilan pada rentang nominal Rp 2 juta sampai dengan 4 juta. Tingkat pendidikannya adalah sarjana dengan jenis kelamin perempuan. Klaster ini telah menggunakan layanan internet banking dalam rentang periode 2 sampai dengan 4 tahun dengan fitur transaksi yang paling sering diakses adalah pengiriman uang dengan menggunakan smartphone.

\section{Klaster 2}

Manfaat utama yang diperoleh dari sejumlah pengguna layanan internet banking pada klaster ini adalah adanya kemudahan proses mendapatkan layanan internet banking dan tidak memerlukan video panduan sebagai fitur bantuan pada website internet banking. Karakteristik demografinya berusia 25-34 tahun, berjenis kelamin perempuan, tingkat pendidikan akhirnya adalah sarjana. Aktivitas kesehariannya adalah sebagai karyawan dengan tingkat penghasilan setiap bulannya pada rentang nominal Rp 4 sampai dengan Rp 6 juta. Periode rentang waktu telah menggunakan layanan internet banking adalah lebih dari lima tahun. Smartphone sebagai alat yang paling sering digunakan untuk akses fitur pengiriman uang.

\section{Klaster 3}

Kemudahan pengoperasian dan proses mendapatkan layanan internet banking yang mudah serta tersedianya fitur bantuan berupa mutasi harian secara rinci merupakan karakteristik dari klaster ini. Berkaitan dengan status sosial, penggunaan layanan internet banking bukan untuk tren tetapi lebih kepada status sosial yang terkesan modern. Mayoritas klaster ini berusia pada rentang 25-34 tahun. Jenis kelamin perempuan mendominasi klaster ini dengan tingkat pendidikan terakhir yang telah ditempuh adalah sarjana. Tingkat penghasilan perbulan pada rentang nominal Rp 4 juta sampai dengan Rp 6 juta. Fitur pengiriman uang merupakan fitur yang paling sering diakses dengan menggunakan smartphone. Periode waktu telah menggunakan layanan internet banking 
adalah pada rentang waktu 4 sampai dengan 5 tahun.

\section{Klaster 4}

Klaster ini lebih berfokus pada manfaat tersedianya fitur bantuan berupa fitur mutasi harian transaksi yang rinci, namun demikian pengguna layanan internet banking pada klaster ini tidak yakin dengan keamanan data pribadi melalui internet banking. Fitur transaksi yang paling sering diakses adalah cek tagihan dan pengiriman uang. Smartphone merupakan alat yang paling sering digunakan untuk akses fitur-fitur transaksi tersebut. Klaster ini telah menggunakan layanan internet banking dalam kurun waktu lebih dari 5 tahun. Mayoritas klaster ini, berusia pada rentang 25-34 tahun. Pekerjaannya adalah sebagai karyawan dengan tingkat penghasilan pada rentang nominal Rp 2 juta sampai dengan 4 juta. Mayoritas berjenis kelamin perempuan. Tingkat pendidikan terakhir adalah sarjana.

\section{KESIMPULAN}

1. K-means clustering menghasilkan 4 klaster : a) klaster pertama berorientasi pada penghematan waktu, b) klaster kedua berorientasi pada kemudahan mendapatkan layanan dan mengoperasionalkan internet banking sehingga gugus ini tidak membutuhkan fitur tambahan seperti panduan video untuk menggunakan internet banking, c) klaster ketiga berorientasi pada gaya hidup modern serta kemudahan mendapatkan layanan dan mengoperasionalkan internet banking dengan manfaat dapat memperoleh rincian transaksi mutasi harian, d) klaster keempat, lebih berfokus pada manfaat tersedianya fitur bantuan berupa fitur mutasi harian transaksi yang rinci, namun demikian pengguna layanan internet banking pada tidak yakin dengan keamanan data pribadi melalui internet banking

2. Fitur layanan internet banking pengiriman uang merupakan fitur yang mendominasi dari ke-empat klaster. Artinya sejumlah responden pada penelitian ini telah melakukan transaksi keuangan melalui internet banking.

3. Hasil tabulasi silang pada periode waktu telah menggunakan layanan internet banking diketahui, mayoritas menggunakan layanan tersebut pada rentang waktu lebih dari 5 tahun, artinya pengguna layanan internet banking pada penelitian ini merupakan pelanggan yang sudah lama berinteraksi dengan penggunaan internet banking.

\section{DAFTAR PUSTAKA}

Akinci, S., Safak, Aksoy., dan Eda, Antilgan. (2004). Adoption of Internet Banking Among Sophisticated Consumer Segments in An Advanced Developing Country, International Journal of Bank Marketing, Vol 22, No 3, pp 212-232.s

Alfansi, Lizar, dan Adrian Sargeant. (2000). Market Segmentation in the Indonesian Banking Sector: The relationship between demographics and desired customer benefits, International Journal of Bank Marketing, Vol 18, No 2, pp 64-74.

Asosiasi Penyelenggara Jasa Internet Indonesia. (2015). Profile Pengguna Internet Indonesia 2014, diunduh tanggal 11 Januari 2016, dari https://www.sendspace.com/file/mke4i $\mathrm{g}$

Bank Indonesia. (2012). Mengenal Electronic Banking, diunduh tanggal 12 Januari 2016, dari http://www.bi.go.id/NR/rdonlyres/24C DE8AA-F4F1-4523-9FCE7F92A5A96DC6/1490/MengenalElectr onicBanking.pdf.

Chih-Chin, Liang., Chung-Wen Yang., PeiChing Wu., Chu-Fen Li. (2012). Market Segmentation to Mobile Banking Service, Advances in Information Science and Service Sciences, Vol 4, No 19, pp 197-204.

Ghozali, Imam. (2011), Aplikasi Analisis Multivariate dengan Program IBM SPSS 19, Edisi 5, Semarang: Badan Penerbit Universitas Diponegoro. 
Hair, Joseph F., William C. Black., Barry J.Babin., Rolph E.Anderson., Ronald L. Tatham. (2010). Multivariate Data Analysis, $7^{\text {th }}$ ed, Upper Saddle River: Pearson Prentice Hall, Inc.

Haley, Russell I. (1968). Benefit Segmentation: Decision-oriented Research Tool, Journal of Marketing, Vol 32, pp 30-35.

Kotler, Philip dan Gary Armstrong. (2016). Principles of Marketing Global, Global Edition, $16^{\text {th }}$ ed, Upper Saddle River: Pearson Education Limited.

Kotler, Philip dan Kevin Lane Keller. (2016). Marketing Management, $14^{\text {th }}$ ed, Upper Saddle River: Pearson Education Limited.

Maenpaa, Katariina. (2006). Clustering The Consumers on the Basis of Their Perceptions of the Internet Banking Services. Internet Research, Vol 16, pp 304-332.

McDonald, Malcom dan Ian Dunbar. (2004). Market Segmentation, London: Licensing Agency Ltd.

Minhas, Raj Singh dan Everett M. Jacob. (1996). "Benefit Segmentation by Factor Analysis: an improved method of targeting consumers for financial services. International Journal of Bank Marketing, Vol 14, No 3, pp 3-14.

Mullins, John W., Orville C, Walker., Harper, W Boyd. (2008). Marketing Management, A Strategic DecisionMaking Approach, $6^{\text {th }}$ ed, New York: McGraw-Hill Irwin.

Plummer, Joseph T. (1974). The Concept and Application of Life Style Segmentation, Journal of Marketing, Vol 38, pp 33-37.

Price Waterhouse Coopers. (2015). Indonesian Banking Survey 2015, diunduh tanggal 12 Januari 2016, dari https://www.pwc.com/id/en/publication s/assets/banking-survey-2015.pdf.

Sharingvision.com. (2015) Pertumbuhan Internet Banking di Indonesia, diakses tanggal 11 Januari 2015, dari http://sharingvision.com/2015/05/pertu mbuhan-internet-banking-di-indonesia/
Snellman, Kaisa. (2000). From One Segment to A Segment of One - The Evolution of Market Segmentation Theory (Working Papers, Swedish School of Economics and Business Administration, 2000). Working Papers, 16. Diunduh tanggal 30 Mei 2013 dari https://helda.helsinki.fi/bitstream/handl e/10227/128/416-951-555-629-

5.pdf? sequence $=2$.

We are social.com. (2016). Digital in 2016, diunduh tanggal 17 Pebruari 2016 dari http://www.slideshare.net/wearesocials g/digital-in-2016

Wells, William D., Douglas J, Tigert. (1971). Activities, Interests and Opinions, Journal of Advertising Research, Vol 11, No 4, pp 27-35.

Yankelovich, Daniel. (1963). New Criteria for Market Segmentation, Harvard Business Review, Vol 42, pp. 83-95.

Yankelovich, Daniel dan David Meer. (2006). Rediscovering Market Segmentation, Harvard Business Review, Vol 84, pp. 122-131.

Yunianto, Ahmad dan Catur Sugiyanto. (2003). Benefit Segmentation Case of a National Bank's Customers in Indonesia, Gadjah Mada International Journal of Business, Vol 5, No 3, pp. 301-319. 